\title{
Chronic Pain and Fear-Avoidance Beliefs: A Narrative Review
}

\author{
Vrushali P. Panhale ${ }^{1}$, Prachita P. Walankar ${ }^{2}$, Sayali S. Khedekar ${ }^{3}$ \\ ${ }^{1}$ Professor, ${ }^{2}$ Assistant Professor, ${ }^{3}$ MPT Scholar, \\ MGM College of Physiotherapy, Navi Mumbai - 400705. \\ Corresponding Author: Prachita P. Walankar
}

\begin{abstract}
Chronic pain has an impact not only on the physical function but also affects the quality of life of an individual. Psychosocial factors play an important role in mediating chronic pain. Fear-avoidance belief is considered as the important psychosocial factor in predicting patient's avoidance for work and physical activity as well as disability and has strong association with chronic pain. The aim of the study is to review the studies on the relationship between chronic pain and fear-avoidance beliefs. Articles from the PubMed, Research gate, Google Scholar and APTA databases were searched for this narrative review with related keywords like chronic pain, chronic musculoskeletal pain, fear avoidance beliefs, psychosocial factors and quality of life. Total fifteen articles were found. Out of which, five were excluded and ten were studied further. The sum of evidences proves that the fearavoidance belief is an important predictor of pain. Through this we conclude that the anticipation of chronic pain can further provoke fear-avoidance behaviour and can give rise to a vicious cycle, in which fear can contribute to avoidance of physical activity and work leading to disability.
\end{abstract}

Key words: chronic, pain, fear avoidance beliefs.

\section{INTRODUCTION}

Pain, an unpleasant sensory and emotional experience, is often associated with actual or potential tissue damage, or describe in terms of such damage. ${ }^{[1]}$ The International Association for the Study of Pain (IASP) has defined Chronic Pain as persistent or recurrent pain lasting longer than 3 months. ${ }^{[2]}$ The worldwide prevalence of chronic pain is $20 \%$ and can range between $2 \%$ and $50 \%$ depending upon certain factors like, region, country, age, gender, etc. ${ }^{[3,4]}$ A recently published study stated that the prevalence of chronic pain is $19.3 \%$ with higher prevalence seen in women $(25.2 \%)$ and it increased steeply beyond the age of 65 years old. Also, a significant impact of chronic pain was observed on work and daily function. ${ }^{[5]}$

Chronic pain is mostly associated with musculoskeletal disorders. [6] A persistent or recurrent pain that arises as part of a disease process directly affecting bone(s), joint(s), muscle(s), or related soft tissue(s) is defined as chronic musculoskeletal pain. ${ }^{[2]}$ Multiple studies done in India, reports high prevalence of chronic musculoskeletal pain, almost $37 \%$ in males and $51 \%$ in females. [7] This musculoskeletal pain could be because of other pains, such as, back pain, knee pain, upper limb pain or neck pain. An Indian study conducted in 2018 reports highest incidence of chronic back pain (24.84\%), followed by chronic knee pain $(16.77 \%)$, chronic upper limb pain (10.87\%) and least prevalence in chronic neck pain $(3.11 \%) .{ }^{[8]}$

Chronic pain affects the patient's daily functioning and causes severe consequences for society. ${ }^{[9]}$ It not only affects the patient as well as their families, professional and social environment, thus 
disrupting the quality of life. ${ }^{[10]}$ Also leads to high economic costs mainly because of functional disability, absenteeism and job loss. ${ }^{[11]}$ Thus, as a solution most of people avoid doing activities in order to reduce the pain.

Psychosocial factors play an important role in mediating chronic pain. ${ }^{[12]}$ An initial episode of damage, there is cascade of changes that take place involving pain related fear, catastrophizing thoughts, kinesiophobia and avoidant behaviour. This directly has an impact on the patient's recovery process which leads to the negative pain experience. ${ }^{[13]}$ This further causes avoidance of functional activities, increased pain sensitivity, psychologic distress and chronic disability affecting the physical and mental health related quality of life. ${ }^{[14]}$ This in turn acts like a barrier and decreased adherence to therapeutic management. ${ }^{[13]}$

Fear-avoidance belief is considered as the important psychosocial factor in predicting patient's avoidance for work and physical activity as well as disability and has strong association with chronic pain. ${ }^{[15,}$ 16] Fear-avoidance belief questionnaire (FABQ) described by Waddle et. al. is used as a standardized self-report measure for assessing patient's anticipated pain and avoidance of physical activity and work. ${ }^{[17]}$ The FABQ has been used in patients with chronic low back pain and has demonstrated good reliability and validity. ${ }^{[17]}$

During $19^{\text {th }}$ and $20^{\text {th }}$ century, biomedical model of pain was followed, which correlated the tissue damage to the pain sensations. ${ }^{[18]}$ Hence, stating that the pain will resolve once the tissue damage is fixed. This model however more favors the acute pain and is unable to justify the other pain in absence of physical damage. [18] Because of this lacuna, the researchers started recognizing and considering psychosocial factors. [18] In 1977, the concept of Biopsychosocial model, that focuses on interaction of physical factors with personal and environmental factors have an impact on body function and structure, activity performance and social participation. [19] This model recognizes both disease and illness, with illness being viewed as the complex interaction of biological, psychological and social factors. $[18,20]$

Fear of pain and/or injury has received an empirical attention for understanding the level of disability in patients with persistent musculoskeletal pain over the years. ${ }^{[21]}$ Pain-related fear has been identified in the general population as well as in various patients' groups with persistent musculoskeletal pain.

Hence, this study extends previous efforts by reviewing large number of papers published on chronic pain and fearavoidance beliefs. The aim of the study is to review the studies on the relationship between chronic pain and fear-avoidance beliefs.

\section{METHODS}

Articles from the PubMed, Research gate, Google Scholar and APTA databases were searched for this narrative review. The related keywords included: chronic pain, chronic musculoskeletal pain, fear avoidance beliefs, psychosocial factors and quality of life. The selection process of the articles was: Full-text articles from peerreviewed journal, Cross-sectional, metaanalysis and systematic review studies and the articles whose title being related to the topic i.e., defining the relationship between chronic pain, fear-avoidance beliefs and quality of life. The studies which did not evaluate the relation of these outcomes were excluded from the study. Also, randomized control trials and experimental studies and articles in other than English language were excluded. Total fifteen articles were found. Out of which, five were excluded. The most relevant information was collected from the ten studies in the tabular format. 
Table 1: Studies on chronic pain and fear-avoidance beliefs:

\begin{tabular}{|c|c|c|c|}
\hline Reference & Study type & Title & Results and Conclusion \\
\hline $\begin{array}{l}\text { Lethem } \\
\text { et.al, }{ }^{[25]} \\
(1983)\end{array}$ & A paper & $\begin{array}{l}\text { Outline of a fear-avoidance model of } \\
\text { exaggerated pain perception-I }\end{array}$ & $\begin{array}{l}\text { It describes a theoretical model for exaggerated pain } \\
\text { perception which has been generated from a } \\
\text { multidisciplinary team approach to the problem of chronic } \\
\text { low-back pain. }\end{array}$ \\
\hline $\begin{array}{l}\text { Vlaeyen } \\
\text { et.al, }{ }^{[13]} \\
(2000)\end{array}$ & A review & $\begin{array}{l}\text { Fear-avoidance and its consequences in } \\
\text { chronic musculoskeletal pain: a state of } \\
\text { the art }\end{array}$ & $\begin{array}{l}\text { This paper reviewed the existing evidence for the mediating } \\
\text { of role of pain-related fear and its consequences on chronic } \\
\text { pain disability. Through this review, authors concluded that } \\
\text { the pain-related fear and avoidance appears to be an } \\
\text { essential feature of the development of a chronic problem in } \\
\text { patients with musculoskeletal pain. Hence, fear-avoidance } \\
\text { needs to be considered in clinical practice and given priority } \\
\text { in research. }\end{array}$ \\
\hline $\begin{array}{l}\text { Linton } \\
\text { et.al, }{ }^{[21]} \\
(2000)\end{array}$ & $\begin{array}{l}\text { A prospective } \\
\text { study }\end{array}$ & $\begin{array}{l}\text { Are fear-avoidance beliefs related to the } \\
\text { inception of an episode of back pain? a } \\
\text { prospective study }\end{array}$ & $\begin{array}{l}\text { The study evaluated prospectively the effects of fear- } \\
\text { avoidance beliefs and catastrophizing on the development of } \\
\text { an episode of self-reported pain and associated physical } \\
\text { functioning. A sample of } 415 \text { health subjects with no spinal } \\
\text { pain were studied. Pain beliefs and avoidance behaviour was } \\
\text { evaluated at initial contact and one year follow up. It was } \\
\text { observed that } 19 \% \text { reported back pain at one-year follow-up. } \\
\text { It emphasized that fear-avoidance beliefs are important in } \\
\text { the development of a pain and might be of use as a } \\
\text { screening tool. }\end{array}$ \\
\hline $\begin{array}{ll}\text { Guclu } & \text { et } \\
\text { al, }{ }^{[26]} & \\
(2012) & \end{array}$ & $\begin{array}{l}\text { A cross- } \\
\text { sectional. } \\
\text { Correlational } \\
\text { study }\end{array}$ & $\begin{array}{l}\text { The Relationship Between Disability, } \\
\text { Quality of Life and Fear-Avoidance } \\
\text { Beliefs in Patients with Chronic Low } \\
\text { Back Pain }\end{array}$ & $\begin{array}{l}\text { This study investigated the relationship between fear } \\
\text { avoidance beliefs, disability and quality of life in } 105 \\
\text { chronic low back pain. According to the results, as pain } \\
\text { intensity increased, higher levels of anxiety, depression and } \\
\text { FABQ-W lead to higher level of disability. }\end{array}$ \\
\hline $\begin{array}{l}\text { Myhre } \\
\text { et.al, }{ }^{27]} \\
(\mathbf{2 0 1 3})\end{array}$ & $\begin{array}{l}\text { A cross- } \\
\text { sectional study }\end{array}$ & $\begin{array}{l}\text { Fear-avoidance beliefs associated with } \\
\text { perceived psychological and social } \\
\text { factors at work among patients with neck } \\
\text { and back pain: a cross- } \\
\text { sectional multicentre study }\end{array}$ & $\begin{array}{l}\text { A cross-sectional multicenter study was conducted in } 373 \\
\text { patients on sick leave due to neck and back pain to evaluate } \\
\text { psychosocial work factors and fear avoidance beliefs. There } \\
\text { was an association between psychological and social factors } \\
\text { at work and fear-avoidance beliefs about work in sick-listed } \\
\text { neck and back patients. }\end{array}$ \\
\hline $\begin{array}{l}\text { Chung } \\
\text { et.al, }{ }^{28]} \\
(2013)\end{array}$ & $\begin{array}{l}\text { A correlational } \\
\text { study }\end{array}$ & $\begin{array}{l}\text { A study of the relationship among fear- } \\
\text { avoidance beliefs, pain and disability } \\
\text { index in patients with low back pain }\end{array}$ & $\begin{array}{l}\text { The study determined the relationship among fear-avoidance } \\
\text { beliefs, pain and disability index in fifty-five patients with } \\
\text { low back pain and also identified factors having an influence } \\
\text { on the mentioned components. It reported that fear } \\
\text { avoidance beliefs had an association with pain and } \\
\text { disability. It emphasized that that screening for fear } \\
\text { avoidance beliefs may be useful for identification of patients } \\
\text { at risk of psychological problems as well as pain intensity } \\
\text { and physical impairment. }\end{array}$ \\
\hline $\begin{array}{l}\text { Dueñas } \\
\text { et.al, }{ }^{[29]} \\
\text { (2016) }\end{array}$ & $\begin{array}{l}\text { A Literature } \\
\text { review }\end{array}$ & $\begin{array}{l}\text { A review of chronic pain impact on } \\
\text { patients, their social environment and the } \\
\text { health care system. }\end{array}$ & $\begin{array}{l}\text { This review assessed several aspects of how chronic pain } \\
\text { influences the patient's daily activities and quality of life, as } \\
\text { well as its repercussions in the workplace, and on the family } \\
\text { and social environment. It concluded that in addition to the } \\
\text { serious consequences on the patient's life, it has a severe } \\
\text { detrimental effect on their social and family environment, as } \\
\text { well as on health care services. }\end{array}$ \\
\hline $\begin{array}{l}\text { Gatchell } \\
\text { et.al, }{ }^{[20]} \\
(\mathbf{2 0 1 6})\end{array}$ & A review & Fear-avoidance beliefs and chronic pain & $\begin{array}{l}\text { This review summarized that fear-avoidance beliefs are } \\
\text { significantly associated with the experience of pain, } \\
\text { especially when the pain becomes chronic in nature. The } \\
\text { authors have found strong evidence that fear-avoidance } \\
\text { beliefs are closely related to increased pain and physical } \\
\text { disability, as well as long-term sick leave. }\end{array}$ \\
\hline $\begin{array}{l}\text { Edwards et } \\
\text { al, }{ }^{[30]} \\
(2016)\end{array}$ & A paper & $\begin{array}{l}\text { The role of psychosocial processes in the } \\
\text { development and maintenance of chronic } \\
\text { pain disorders }\end{array}$ & $\begin{array}{l}\text { It focused on psychosocial factors that may influence the } \\
\text { diagnosis and trajectory of chronic pain disorders. The } \\
\text { authors concluded that, the complexity and profound } \\
\text { variability in chronic pain highlights the need to better } \\
\text { understand the multidimensional array of interacting forces } \\
\text { that determine the trajectory of chronic pain conditions. }\end{array}$ \\
\hline $\begin{array}{l}\text { Panhale et } \\
\text { al, }{ }^{[32]} \\
(\mathbf{2 0 1 6})\end{array}$ & $\begin{array}{l}\text { A correlational } \\
\text { study }\end{array}$ & $\begin{array}{l}\text { Association of physical performance and } \\
\text { fear-avoidance beliefs in adults with } \\
\text { chronic low back pain. }\end{array}$ & $\begin{array}{l}\text { The study evaluated association between activity limitation } \\
\text { and fear-avoidance belief in chronic low back pain patients. } \\
\text { A strong relationship exists between elevated fear avoidance } \\
\text { beliefs and activity limitation in patients with chronic low } \\
\text { back pain. }\end{array}$ \\
\hline
\end{tabular}

\section{DISCUSSION}

The impact of chronic pain on various healthcare systems and quality of life has been reported by several authors. Several studies have found the strong correlation between chronic pain and 
reduced physical activity thus affecting activities of daily living. ${ }^{[34]}$ A recently published study has reported that chronic pain leads to reduced level of self-reported physical activity. ${ }^{[35]}$ Fear-avoidance beliefs are strongly associated with the chronic pain. ${ }^{[18]}$ The sum of evidences proves that the fear-avoidance belief is an important predictor of pain episodes and has been included in a screening questionnaire to detect patient at risk of developing persistent problems. ${ }^{[18,21]}$ Hence, anyone who assesses and treat pain-related disability should also be assess and treat pain-related fear-avoidance beliefs. Increased fear during any physical activity in low back pain patients results in longterm consequences in the initiation and maintenance of chronic pain disability. ${ }^{[13]}$

Fear-avoidance behaviours are associated in an important way to the evolution and transition towards chronicity of musculoskeletal pain disorders. ${ }^{[36,37]}$ The fear avoidance model focuses on patients' beliefs about disease, movement, and pain due to erroneous thoughts about the nociceptive experience. This being a vicious cycle leads to avoidance of activities, hypervigilance behaviours and catastrophic thoughts that in turn, augments the disability and pain. ${ }^{[37]}$ High levels of fear-avoidance behaviours are associated with activity limitation, participation restriction and increased disability which has an impact on the recovery process. ${ }^{[13]}$ In adjunct to this, there is a substantial evidence that fearavoidance beliefs emerge as a major factor that predisposes to long term illness in chronic pain. However, their predictive value in acute pain is ambiguous. [38] Another study investigated the relationship between pain, physical performance and disability in 50 chronic low back pain patients. It revealed Association between $\underset{39]}{\text { pain, }}$ physical performance and disability.

Also, literature shows that adolescent population with chronic pain have higher psychological impact in terms of neurosis, failure and have less social acceptance and coping behaviours. [40] Burton et.al. reported that the $59 \%$ of disability is associated with chronic pain. Also, psychological factors influence the long-term disability. ${ }^{[41]}$ Pain-related fear is more associated with perceived disability and reduced behavioural performance than with pain itself. ${ }^{[42]}$ Some studies reported positive relationship between chronic pain and quality of life however, there are limited evidences. Patients with severe and frequent pain show poor quality of life than patients with moderate and less frequent pain. ${ }^{[43]} \mathrm{A}$ systematic review and meta-analysis stated that health-related quality of life in chronic low back pain patients is an important issue because it can predict the probability of recovery. ${ }^{[44]}$

Through this we conclude that the anticipation of chronic pain can further provoke fear-avoidance behaviour and can give rise to a vicious cycle, in which fear can contribute to avoidance of physical activity and work leading to disability. Thus, fear-avoidance beliefs should be incorporated while screening the patients and targeted during rehabilitation for successful outcome.

The limitation of the study is lack of statistical analysis and evaluation criteria of the included studies. In future, systematic review could be done for clearer picture especially related to quality of life and fearavoidance beliefs and more data can be collected from other databases which focus on the topic and try incorporating the statistical analysis of the data where it is possible.

Acknowledgement: None

\section{Conflict of Interest: None}

\section{Source of Funding: None}

\section{REFERENCES}

1. Treede RD. The International Association for the Study of Pain definition of pain: as valid in 2018 as in 1979 , but in need of regularly updated footnotes. Pain Rep. 2018 
Mar 5;3(2): e643. doi: 10.1097/PR9.0000000000000643.

2. Treede RD, Rief W, Barke A, Aziz Q, Bennett MI, Benoliel R, Cohen M, Evers S, Finnerup NB, First MB, Giamberardino MA, Kaasa S, Kosek E, Lavand'homme P, Nicholas M, Perrot S, Scholz J, Schug S, Smith BH, Svensson P, Vlaeyen JWS, Wang SJ. A classification of chronic pain for ICD-11. Pain. 2015 Jun;156(6):10031007. doi: 10.1097/j.pain.0000000000000160.

3. van Hecke O, Torrance $\mathrm{N}$, Smith $\mathrm{BH}$. Chronic pain epidemiology and its clinical relevance. $\mathrm{Br} \quad \mathrm{J}$ Anaesth. 2013 Jul;111(1):13-8. doi: 10.1093/bja/aet123.

4. Reid KJ, Harker J, Bala MM, Truyers C, Kellen E, Bekkering GE, Kleijnen J. Epidemiology of chronic non-cancer pain in Europe: narrative review of prevalence, pain treatments and pain impact. Curr Med Res Opin. 2011 Feb;27(2):449-62. doi: 10.1185/03007995.2010.545813.

5. Saxena AK, Jain PN, Bhatnagar S. The Prevalence of Chronic Pain among Adults in India. Indian J Palliat Care. 2018 OctDec;24(4):472-477. doi: 10.4103/IJPC.IJPC_141_18.

6. Sarahroodi S, Maleki-Jamshid A, Sawalha AF, Mikaili P, Safaeian L. Pattern of selfmedication with analgesics among Iranian University students in central Iran. J Family Community Med. 2012 May;19(2):125-9. doi: 10.4103/2230-8229.98302.

7. Muthunarayanan L, Ramraj B, Russel JK. Prevalence of pain among rural adults seeking medical care through medical camps in Tamil Nadu. Indian $\mathbf{J}$ Pain 2015;29:36-40.

8. Deshpande A. Prevalence of chronic pain based on primary health center data from a city in central India. Indian $\mathbf{J}$ Pain. 2018;32:81.

9. Breivik H, Collett B, Ventafridda V, Cohen R, Gallacher D. Survey of chronic pain in Europe: prevalence, impact on daily life, and treatment. Eur J Pain. 2006 May;10(4):287-333.

doi: 10.1016/j.ejpain.2005.06.009.

10. Dueñas M, Ojeda B, Salazar A, Mico JA, Failde I. A review of chronic pain impact on patients, their social environment and the health care system. J Pain Res. 2016 Jun 28;9:457-67. doi: 10.2147/JPR.S105892.
11. Vlaeyen JWS, Kole-Snijders AMJ, Boeren RGB, van Eek H. Fear of movement/(re)injury in chronic low back pain and its relation to behavioral performance. Pain. 1995 Sep;62(3):363-372. doi: 10.1016/0304-3959(94)00279-N.

12. Ferreira-Valente MA, Pais-Ribeiro JL, Jensen MP. Associations between psychosocial factors and pain intensity, physical functioning, and psychological functioning in patients with chronic pain: a cross-cultural comparison. Clin J Pain. 2014 Aug;30(8):713-23. doi: 10.1097/AJP.0000000000000027.

13. Vlaeyen JWS, Linton SJ. Fear-avoidance and its consequences in chronic musculoskeletal pain: a state of the art. Pain. 2000 Apr;85(3):317-332. doi: 10.1016/S0304-3959(99)00242-0.

14. Rosenstiel AK, Keefe FJ. The use of coping strategies in chronic low back pain patients: relationship to patient characteristics and current adjustment. Pain. 1983 Sep;17(1):33-44. doi: 10.1016/03043959(83)90125-2.

15. Al-Obaidi SM, Nelson RM, Al-Awadhi S, Al-Shuwaie N. The role of anticipation and fear of pain in the persistence of avoidance behavior in patients with chronic low back pain. Spine (Phila Pa 1976). 2000 May 1;25(9):1126-31. doi: 10.1097/00007632200005010-00014.

16. Al-Obaidi SM, Beattie P, Al-Zoabi B, AlWekeel S. The relationship of anticipated pain and fear avoidance beliefs to outcome in patients with chronic low back pain who are not receiving workers' compensation. Spine (Phila Pa 1976). 2005 May 1;30(9):1051-7. doi: 10.1097/01.brs.0000160848.94706.83.

17. Waddell G, Newton M, Henderson I, Somerville D, Main CJ. A Fear-Avoidance Beliefs Questionnaire (FABQ) and the role of fear-avoidance beliefs in chronic low back pain and disability. Pain. 1993 Feb;52(2):157-168. doi: 10.1016/03043959(93)90127-B.

18. Gatchel RJ, Peng YB, Peters ML, Fuchs PN, Turk DC. The biopsychosocial approach to chronic pain: scientific advances and future directions. Psychol Bull. 2007 Jul;133(4):581-624. doi: 10.1037/0033-2909.133.4.581.

19. Engel GL. The need for a new medical model: a challenge for biomedicine. 
Science. 1977 Apr 8;196(4286):129-36. doi: 10.1126/science. 847460 .

20. Gatchel RJ, Neblett R, Kishino N, Ray CT. Fear-Avoidance Beliefs and Chronic Pain. J Orthop Sports Phys Ther. 2016 Feb;46(2):38-43. 10.2519/jospt.2016.0601.

21. Linton SJ, Buer N, Vlaeyen J, Hellsing AL. Are fear-avoidance beliefs related to the inception of an episode of back pain? A prospective study. Psychol Health. 2000 Nov; 14(6):1051-9. doi: 10.1080/08870440008407366.

22. Buer N, Linton SJ. Fear-avoidance beliefs and catastrophizing: occurrence and risk factor in back pain and ADL in the general population. Pain. 2002;99(3):485-491.

23. Heneweer H, Aufdemkampe G, van Tulder MW, Kiers H, Stappaerts KH, Vanhees L. Psychosocial variables in patients with (sub)acute low back pain- an inception cohort in primary care physical therapy in the Netherlands. Spine. 2007;32(5):586592.

24. Lundberg M, Carlsson S, Styf J. A psychometric evaluation of the Tampa Scale for Kinesiophobia-from a physiotherapeutic perspective. Physiotherapy Theory and Practice. 2004;20(2):1-13.

25. Lethem J, Slade PD, Troup JD, Bentley G. Outline of a Fear-Avoidance Model of exaggerated pain perception--I. Behav Res Ther. 1983;21(4):401-8. doi: 10.1016/00057967(83)90009-8.

26. Guclu DG, Guclu O, Ozaner A, Senormanci O, Konkan R. The relationship between disability, quality of life and fear-avoidance beliefs in patients with chronic low back pain. Turk Neurosurg. 2012;22(6):724-31. doi: 10.5137/1019-5149.JTN.6156-12.1.

27. Myhre K, Røe C, Marchand GH, Keller A, Bautz-Holter E, Leivseth G, Sandvik L, Lau B. Fear-avoidance beliefs associated with perceived psychological and social factors at work among patients with neck and back pain: a cross-sectional multicentrestudy. BMC MusculoskeletDisord. 2013 Nov 21;14:329. doi: 10.1186/1471-2474-14-329.

28. Chung EJ, Hur YG, Lee BH. A study of the relationship among fear-avoidance beliefs, pain and disability index in patients with low back pain. J ExercRehabil. 2013 Dec 31;9(6):532-5. doi: 10.12965/jer.130079.

29. Dueñas M, Ojeda B, Salazar A, Mico JA, Failde I. A review of chronic pain impact on patients, their social environment and the health care system. J Pain Res. 2016 Jun 28;9:457-67. doi: 10.2147/JPR.S105892.

30. Edwards RR, Dworkin RH, Sullivan MD, Turk DC, Wasan AD. The Role of Psychosocial Processes in the Development and Maintenance of Chronic Pain. J Pain. 2016 Sep;17(9 Suppl):T70-92. doi: 10.1016/j.jpain.2016.01.001.

31. Yamada K, Matsudaira $K$, Imano $H$, Kitamura A, Iso $\mathrm{H}$. Influence of workrelated psychosocial factors on the prevalence of chronic pain and quality of life in patients with chronic pain. BMJ Open. 2016 Apr 25;6(4):e010356. doi: 10.1136/bmjopen-2015-010356.

32. Panhale VP, Gurav RS, Nahar SK. Association of Physical Performance and Fear-Avoidance Beliefs in Adults with Chronic Low Back Pain. Ann Med Health Sci Res. 2016 Nov-Dec;6(6):375-379. doi: 10.4103/amhsr.amhsr_331_15.

33. Lerman SF, Rudich Z, Brill S, Shalev H, Shahar G. Longitudinal associations between depression, anxiety, pain, and painrelated disability in chronic pain patients. Psychosom Med. 2015 Apr;77(3):333-41. doi: 10.1097/PSY.0000000000000158.

34. Azevedo LF, Costa-Pereira A, Mendonça L, Dias CC, Castro-Lopes JM. Epidemiology of chronic pain: a population-based nationwide study on its prevalence, characteristics and associated disability in Portugal. J Pain. 2012 Aug;13(8):773-83. doi: 10.1016/j.jpain.2012.05.012.

35. McBeth J, Nicholl BI, Cordingley L, Davies KA, Macfarlane GJ. Chronic widespread pain predicts physical inactivity: results from the prospective EPIFUND study. Eur J Pain. 2010 Oct;14(9):972-9. doi: 10.1016/j.ejpain.2010.03.005.

36. Luque-Suarez A., Martinez-Calderon J., Falla D. Role of kinesiophobia on pain, disability and quality of life in people suffering from chronic musculoskeletal pain: A systematic review. Br. J. Sports Med. 2019;53:554-559. doi: 10.1136/bjsports-2017-098673.

37. Zale E.L., Lange K.L., Fields S.A., Ditre J.W. The Relation Between Pain-Related Fear and Disability: A Meta-Analysis. $J$. Pain. 2013;14:1019-1030. doi: 10.1016/j.jpain.2013.05.005.

38. Iles R.A., Davidson M., Taylor N.F. Psychosocial predictors of failure to return 
to work in non-chronic non-specific low back pain: A systematic review. Occup. Environ. Med. 2007; 65: 507-517. doi: 10.1136/oem.2007.036046.

39. Verma C, Walankar P, Gurav S. Correlation between pain, physical performance and disability in chronic low back pain patients. International Education and Research Journal. 2018, 4(8); 16-17.

40. Merlijn VP, Hunfeld JA, van der Wouden JC, Hazebroek-Kampschreur AA, Koes BW, Passchier J. Psychosocial factors associated with chronic pain in adolescents. Pain. 2003 Jan;101(1-2):33-43. doi: 10.1016/s0304-3959(02)00289-0.

41. Burton AK, Tillotson KM, Main CJ, Hollis S. Psychosocial predictors of outcome in acute and subchronic low back trouble. Spine (Phila Pa 1976). 1995 Mar 15;20(6):722-8. doi: 10.1097/00007632199503150-00014.

42. Crombez G, Vlaeyen JW, Heuts PH, Lysens R. Pain-related fear is more disabling than pain itself: evidence on the role of painrelated fear in chronic back pain disability. Pain. 1999 Mar;80(1-2):329-39. doi: 10.1016/s0304-3959(98)00229-2.

43. Langley P, Pérez Hernández C, MargaritFerri C, Ruiz Hidalgo D, Lubián López M. Pain, health related quality of life and healthcare resource utilization in Spain. J Med Econ. 2011;14(5):628-38. doi: 10.3111/13696998.2011.604369.

44. Coluccia A, Pozza A, Gusinu R, Gualtieri G, Muzii VF, Ferretti F. Do patients with chronic low-back pain experience a loss of health-related quality of life? A protocol for a systematic review and meta-analysis. BMJ Open. 2020 Feb 9;10(2): e033396. doi: 10.1136/bmjopen-2019-033396.

How to cite this article: Panhale VP, Walankar PP, Khedekar SS. Chronic pain and fearavoidance beliefs: a narrative review. Int $J$ Health Sci Res. 2021; 11(6): 219-225. DOI: https://doi.org/10.52403/ijhsr.20210634 